\title{
CONTINUOUS QUALITY IMPROVEMENT \\ sciendo OF AN ENGINEERING PROGRAM AS A REQUIREMENT FOR ABET ACCREDITATION
}

doi:10.2478/mape-2018-0050

Date of submission of the article to the Editor: 03/2018

Date of acceptance of the article by the Editor: 06/2018

MAPE 2018, volume 1, issue 1, pp. 393-

Michalene Eva Grebski, PhD

Northampton Community College - Monroe Campus, USA

Associate Professor, PhD, Eng. Radosław Wolniak

Silesian University of Technology, Poland

Wieslaw Grebski, Professor Emeritus

The Pennsylvania State University, USA

\begin{abstract}
The paper addresses the benefits from accreditation of an Engineering program. The criteria for accreditation are also being discussed as well as the cost of domestic and outside of the United States (US) accreditation. The paper also contains procedures for curriculum development as well as evaluation and assessment. Implementation of a comprehensive continuous quality improvement process (CQI) for individual courses as well as the entire Engineering program is being discussed and analyzed. The conclusions include practical recommendations for the effective closing of the CQI loop.
\end{abstract}

Keywords: Engineering curriculum, Engineering accreditation, CQI in Engineering education

\section{INTRODUCTION}

The accreditation process for an Engineering program in the United States (US) had been implemented in 1932 (Grebski and Grebski, 2016). The accreditation body, ABET (Accreditation Board for Engineering and Technology), was created and represents Engineering associations and Engineering educational institutions. ABET is not a government agency nor is it associated with any government. The ABET accreditation process is a peer review process using volunteers from different educational institutions and industry as reviewers. ABET criteria were developed by professional Engineering associations jointly with the Society of Engineering Educators (ASEE) (Dudeck and Grebski, 2011; Grebski, 2014, 2015; Grebski and Cai, 2012). ABET's criteria reflects the expectations and recommendations of industry. Most larger Engineering programs in the United States are accredited by ABET. Accreditation can be granted for either three or six years (Accreditation Criteria and Supporting Documents: 2018, Engineering Accreditation Commission, 2016, 2018; www.abet.org Official site; Cai and Grebski, 2011).

Accreditation depends on the strengths and weaknesses of the program which are identified by an ABET review team. Prior to the onsite visit, the University which is to be evaluated prepares a self-study report. This report is matching the program requirements with ABET criteria. ABET accreditation criteria are being reviewed annually. These criteria keep changing to reflect the needs of industry and other external factors. ABET accreditation has four main goals. The goals are as follows:

- Continuous quality improvement (CQI) of Engineering education,

- Uniformity of minimum standards,

- Assistance in obtaining professional registration for graduates, and

- Guidance for students while transferring from one educational institution to another. 


\section{ABET ACCREDITATION FOR PROGRAMS OUTSIDE THE UNITED STATES}

In addition to the accreditation of domestic Engineering programs, ABET is also involved in accrediting programs outside the United States (US). The procedure is very similar to ABET accreditation of programs within the US. The conditions for ABET international accreditation are as follows: (www.abet.org Official site).

- Programs seeking accreditation in countries where English is not the native language must provide their program's name in English and the native language.

(The translation must reflect technical content instead of a literal translation.)

- An official transcript must be provided in English.

- The Self-Study Report must be provided in English.

- The program faculty and administration must be able to communicate in English with the visiting team which is conducting the visiting activities.

- The program must reimburse the ABET team's actual travel expenses.

- The program must provide additional support for insuring the safety and security of the ABET team.

- The program must submit an "Official Request for Evaluation" as well as a "Request for Acknowledgement".

\section{BENEFITS AND COST FACTORS OF ABET PROGRAM ACCREDITATION FOR PROGRAMS OUTSIDE THE UNITED STATES (US)}

The benefits of international ABET accreditation are very similar to those for programs within the United States (US). Those benefits include the following:

- Securing compatibility of the Engineering program with an equivalent program within the United States.

- Elimination of the need for evaluating the credentials of the program graduates while applying for employment or applying for professional registration in the United States.

The cost factor of ABET accreditation outside the United States can be significant and includes the following: (Accreditation Criteria and Supporting Documents: 2018; Engineering Accreditation Commission, 2016; www.abet.org (Official site) (Table 1).

Table 1.

Cost factor of ABET accreditation outside the United States.

\begin{tabular}{|l|l|}
\hline \multicolumn{1}{|c|}{ Cost Factor } & \multicolumn{1}{|c|}{ Cost } \\
\hline Readiness Review & $\$ 1000$ \\
\hline On-site Review & $\$ 8025$ \\
\hline Annual Maintenance Fee & $\$ 1295$ \\
\hline $\begin{array}{l}\text { Reimbursement of the ABET Team's Actual Travel } \\
\text { Expenses }\end{array}$ & $\begin{array}{l}\text { Airfare, hotel, meals, transportation, international calls } \\
\text { and travel insurance }\end{array}$ \\
\hline
\end{tabular}

The readiness review is very important to identify any potential problems with meeting ABET criteria. This is done prior to the on-site visit. If the "readiness review" indicates potential problems which need to be corrected, the on-site accreditation visit can be postponed until those problems are corrected.

Most countries have a national higher educational quality assurance organization. ABET also participates in a global quality assurance process for technical educational programs through numerous agreements with accrediting organizations worldwide. Those agreements include Mutual Recognition Agreements (MRA) or Memoranda of Understanding (MOU). Mutual recognition agreements between the accrediting agency in the country where the program is offered and ABET can also provide similar benefits to graduates of the Engineering program to direct $A B E T$ accreditation. However, this eliminates the need and the cost of double accreditation. 


\section{PROCEDURE FOR CURRICULUM DEVELOPMENT OF AN ENGINEERING PROGRAM}

Curriculum development for an Engineering program needs to start from defining the Program Educational Objectives. The Program Educational Objectives describe what the graduates are expected to attain within a few years after graduation. Program educational objectives need to be developed in cooperation with industry taking under consideration the present and future needs of industry and the employment opportunities for graduates. After the Program Educational Objectives have been clearly defined, the Engineering faculty can develop student outcomes defined as the body of knowledge that Engineering graduates need to have at the time of graduation. Meeting the student outcomes (body of knowledge at the time of graduation) will allow the students to achieve the Program Educational Objectives in the future. After the student outcomes are clearly defined, Engineering faculty in the program can start developing the content of individual courses required by the curriculum. Each course needs to contribute to meeting the student outcomes. (There is no need for a course which does not contribute to the student outcomes.) After the content of each course is developed, the individual faculty teaching the course can develop a course syllabus which is distributed to the students. The flowchart describes the curriculum development of an Engineering program as shown in Fig. 1, (Grebski and Grebski, 2016).

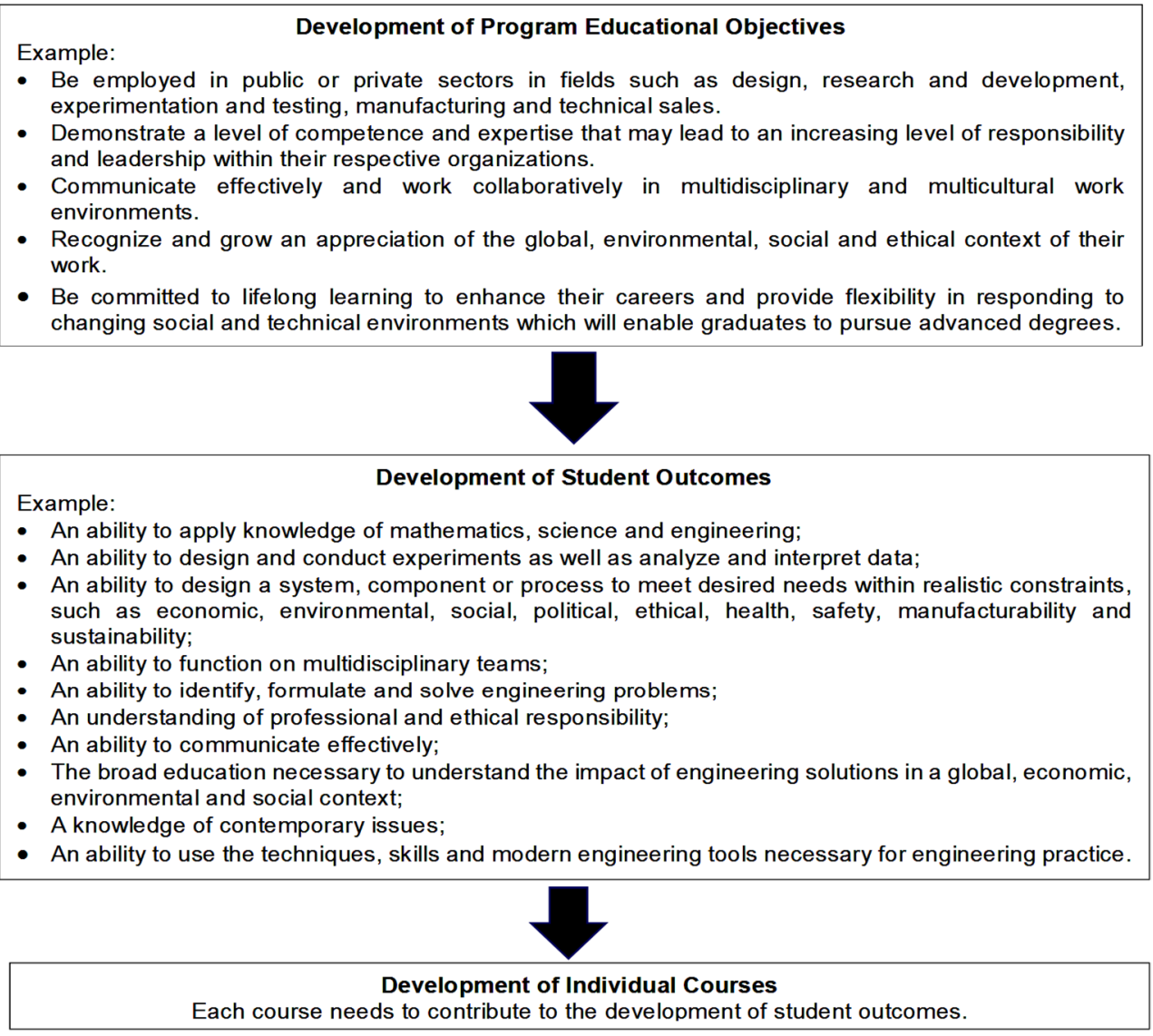

Fig. 1. Procedure for curriculum development for Engineering program

\section{ASSESSMENT OF PROGRAM ACHIEVEMENTS}

Assessment of obtaining student outcomes is very important for the continuous quality improvement (CQI) process. Engineering programs need to identify, collect and prepare assessment data which are needed to evaluate program achievements as well as making adjustment for continuous quality improvements. Assessment data can be collected on a continuous basis from the sources as follow: (Grebski and Grebski, 2016). 
- End of the semester course assessment related to meeting the educational outcomes of the course which are collected from faculty and students - This is done from the purpose of triangulation.

a) Student perspective - This is done by students.

b) Faculty perspective - This is done by the faculty.

c) Student performance - This is done by the faculty.

- Exit interview of graduating students conducted each year by an Industrial Advisory Committee for the Engineering program;

(None of the university employees are present.)

- Scores from the Engineer-in-Training Standardized Exams - This exam is taken by most students in their senior year.

- Capstone Project Assessment

- Alumni Survey

- Employer Survey

- Feedback from the Industrial Advisory Committee

The collected assessment data are being evaluated by the Coordinator of the Engineering program at the end of the Spring semester each academic year. The level of attainment of each student's outcome is being assessed. All outcomes with a level of achievement less that (for example) $80 \%$ are being identified and appropriate changes in the curriculum are being implemented by the Curriculum Committee of the Engineering program. The curricular changes may contain revisions of some courses or even creating of an additional course if there is a need to do so. Once every three years, program educational objectives and program outcomes are being revised to stay current with the needs of industry. Revision(s) of program educational objectives and program outcomes take place with the involvement of the Industrial Advisory Committee representing the needs of industry. The entire assessment and evaluation procedure is well documented and stays in the possession of the Engineering Program Coordinator. During the accreditation visit, those documents are being carefully examined by the ABET evaluating team. The continuous quality improvement loop closes annually. The schematic diagram of the annual program assessment is shown in Fig. 2.

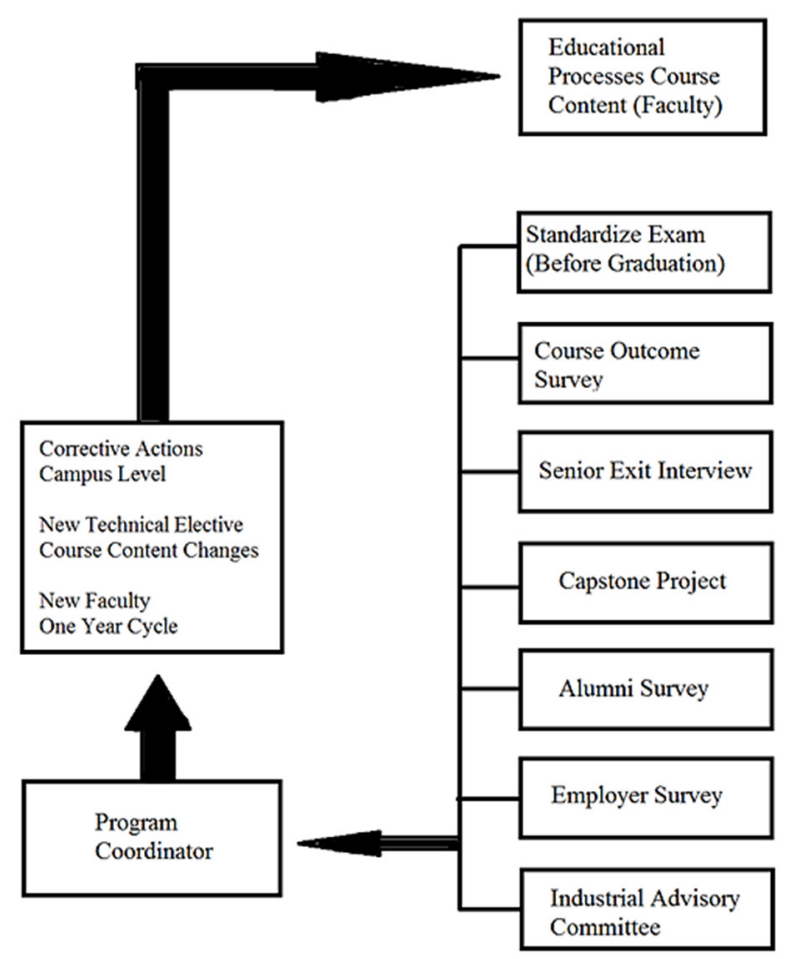

Fig. 2. Flowchart of the annual program assessment 
In addition to the annual program assessment, there is also a CQI process for the assessment of individual courses, so that minor adjustments in course content can be implemented. Those minor changes in the course content can be incorporated by the faculty teaching the course. Each faculty member teaching the course is required to prepare a one-page CQI assessment of the course at the end of every semester. The CQI form prepared by the faculty needs to include the following:

- Strength of the course,

- Weaknesses of the course, and

- Suggested corrective action to improve the quality of the course the next time that it is offered.

A schematic diagram of the semester course review is shown in Fig. 3.

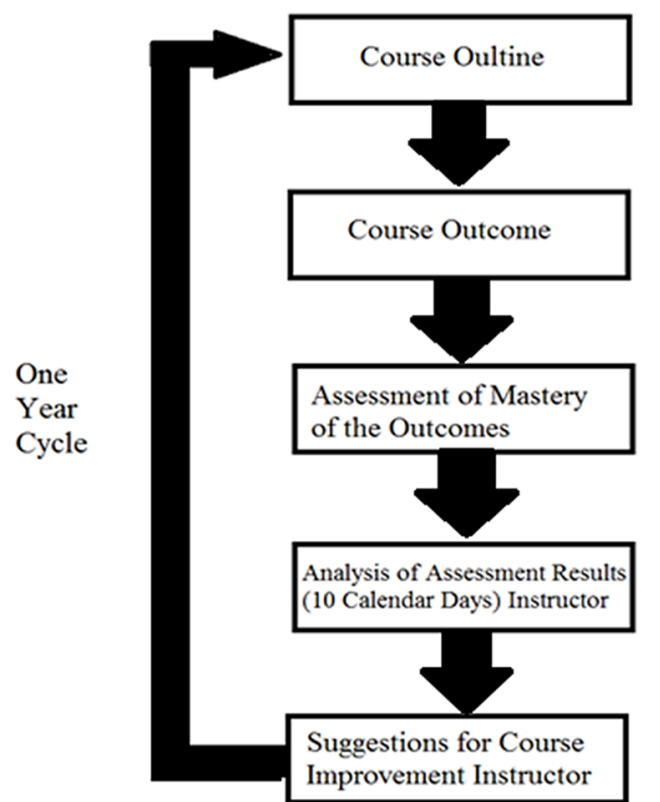

Fig. 3. Flowchart of the semester course review

\section{CONCLUSIONS}

Engineering programs need to reflect the constantly changing needs of industry. Program educational objectives need to be reviewed and revised by the Industrial Advisory Committee periodically. Any changes in program educational objectives require the modification of student outcomes as well as adjustments in individual courses. There is a need for continuous quality improvement for the Engineering program itself as well as for individual courses. Continuous quality improvement allows the program to stay aligned to the expectations of the future employers of graduates. ABET accreditation is very important and helpful for graduates in obtaining professional registration as well as finding employment opportunities. ABET accreditation requirements are not restrictive and allow or even encourage innovative approaches to Engineering education. Accreditation of a program outside of the United States can be helpful to those programs and allows for student exchange, faculty exchange or articulation agreements.

\section{REFERENCES}

ABET. (2018). [online] Available at: www.abet.org (Official site)

Accreditation Criteria and Supporting Documents: www.abet.org/accreditation/accreditation-criteria. DOA: 05.21.2018.

Cai, S. and Grebski, W. (2011). Improve Retention through Implementation of "Toy FUN" Projects, Into Fundamental Engineering Classes. In Proceeding: IAJC-ASEE, Joint International Committee. 
Dudeck, K. and Grebski, W. (2011). New General Engineering Program with Alternative Energy and Power Generation Track at Penn State. In: Proceedings: ASEE New England Regional. Conference. American Society of Engineering Education.

Engineering Accreditation Commission. (2016). Criteria for Accrediting Engineering Programs: Effective for Reviews during the 2016-2017 Accreditation Cycle. October 16, 2015. DOA: 05.21.2018.

Engineering Accreditation Commission. (2018). Criteria for Accrediting Engineering Programs: Effective for Reviews during the 2017-2018 Accreditation Cycle. October 29, 2016. DOA: 05.21.2018.

Grebski, W. (2014). "Recruitment of Engineering Students through Community-Based Programs", in Proceedings: The $12^{\text {th }}$ Latin American and Caribbean Conference on Engineering and Industry, Quayaquil, Ecuador.

Grebski, W. (2015). Teaching Mathematics as a Global Challenge for Engineering Education. In Proceedings: ICIE Conference, 2015.

Grebski, W. and Cai, S. (2012). Partnership with STEM High School as a Recruiting Tool for Engineering Program. In Proceedings: The $10^{\text {th }}$ Latin American and Caribbean Conference for Engineering and Industry, Panama City, Panama.

Grebski, W. and Grebski, M. (2016). "Keeping Technical Education Aligned to the Needs and Expectations of Industry. Management Systems in Production Engineering, 2016, No. 2(22), pp. 77-80. DOI: 10.12914/MSPE-01-02-2016. 